\title{
EARLY EATING HABITS IN INFANTS AND THEIR ASSOCIATION WITH IRON METABOLISM
}

\author{
Inga Elksne ${ }^{1,2, \#}$, leva Strēle ${ }^{3}$, Inese Siksna ${ }^{1,2}$, and Dace Gardovska ${ }^{4,5}$ \\ ${ }^{1}$ Faculty of Medicine, Rīga Stradiṇš University, 16 Dzirciema Str., Rīga, LV-1007, LATVIA \\ 2 Institute of Food Safety, Animal Health, and Environment "BIOR", 3 Lejupes Str., Rīga, LV-1076, LATVIA \\ ${ }^{3}$ Faculty of Public Health and Social Welfare, Rīga Stradinš University, 16 Dzirciema Str., Rīga, LV-1007, LATVIA \\ ${ }^{4}$ Faculty of Pediatrics, Rīga Stradinš University, 16 Dzirciema Str., Rīga, LV-1007, LATVIA \\ ${ }^{5}$ Children's Clinical University Hospital, 45 Vienības Av., Rīga, LV-1004, LATVIA \\ \# Corresponding author, inga.sirina@Idusa.Iv
}

Contributed by Dace Gardovska

\begin{abstract}
Infants experience rapid growth and development during their first year of life. The objective of the study was to investigate the early dietary habits of Latvian infants and their relation to iron metabolism. The study was composed of Study A "Research on eating habits of infants living in Latvia" ( $n=344)$ and Study B "Research on the association between eating habits of infants living in Latvia and iron metabolism" ( $n=73)$. $89 \%$ of infants $(n=18)$ were breastfed (BF) in the first month, and $21 \%(n=15)$ were exclusively $B F$ for the first six months. The average age for introducing complementary food was five months. Iron intake was on average $7.4 \mathrm{mg}$. Iron deficiency (ID) was in 9.6\% $(n=7)$ and iron deficiency anemia (IDA) in $4.1 \%(n=3)$ of infants. The blood iron level was lower in $30 \%(n=8)$ of infants fed with cow's milk. For infants who obtained iron predominantly from non-animal products, serum ferritin (SF) was within normal range. SF was within the normal range for $93 \%(n=26)$ of infants who did not consume legumes. Dietary habits of infants in Latvia partly correspond to the guidelines. $63 \%$ of infants did not consume enough iron from food and ID was observed in $9.6 \%$ of infants and IDA in $4.1 \%$. A lower iron level in blood occurred in breastfed infants and in infants for whom cow's milk was introduced at an early stage; a lower mean corpuscular volume level was observed in infants whose exclusive breastfeeding continued for at least the first four months; lower SF occurred in breastfed infants, in at least the first four months for exclusively breastfed infants, and in infants for whom whose legumes had been introduced in diet. A higher level of soluble transferrin receptors was observed in infants who were not first-born.
\end{abstract}

Keywords: nutrition, breastfeeding, eating habits, iron deficiency.

\section{INTRODUCTION}

There is very rapid growth and development in the first year of life of infants. In this period, the need of the infant's body for nutrients per $1 \mathrm{~kg}$ of body weight is much higher than that of an adult, and therefore the qualitative composition of food is particularly important. During this period of life, eating habits for the whole life are also developed. It is important to study whether the eating habits of infants living in Latvia comply with both the guidelines set out in Latvia and the guidelines of other leading organisations, such as the World Health Organisation (WHO), the European
Food Safety Authority (EFSA) and the European Society for Paediatric Gastroenterology Hepatology and Nutrition (ESPGHAN). It is also interesting to observe how an infant's eating habits change over time.

Iron deficiency is identified as the most frequent deficiency in the first year of life (Domellöf et al., 2014). Lack of iron in the body or iron deficiency can cause irreversible impairment of cognitive development (Baker and Greer, 2010). Errors in an infant's diet are among the main reasons for iron deficiency. Therefore, compliance with the abovementioned healthy eating habits is not only necessary for 
the prevention of diseases in later life, but, above all, for the prevention of iron deficiency. Timely detection of iron deficiency through biomarkers may reduce the risk of anaemia.

It is also important to investigate the association between eating habits and iron metabolism in infants who live in Latvia, taking into account their specific eating habits. If an association between eating habits and iron metabolism cannot be found, other factors that can affect iron metabolism and are characteristic to the population of Latvia should also be studied, such as the eating habits of pregnant women and the prevention of iron deficiency using medicines (Dewey, 2013; Vaivada et al., 2017).

The aim of the study was to investigate early eating habits in Latvian infants and their association with iron metabolism.

\section{MATERIALS AND METHODS}

The study consisted of two parts: Study A "Research on eating habits of infants living in Latvia" and Study B "Research on the association between eating habits of infants living in Latvia and iron metabolism". Part A of the crosssectional study was conducted within the scope of a project supported by the European Food Safety Authority (EFSA) in 2012. Selection criteria of study participants for inclusion in the survey sample were: age, sex, and parental consent to participating in the study. Participants from all regions of Latvia in proportion to the birth indicators specified in the database of the Central Statistical Bureau (CSP) participated in the study.

The procedure for the selection of study participants consisted of two stages. General practitioners and pediatricians registered in the Latvian Medical Associations were invited to participate in the first stage. In the second stage, the medical practitioners were asked to randomly invite part of their patients to participate in the survey.

Data were analysed using the Statistical Package for Social Sciences (SPSS), STATA and Excel software. The National Food Composition Database was used for nutritional data analyses.

For analysis of the age of initiation of complementary feeding, 334 respondents were included in the study group, including those who were at the age of initiation of complementary feeding. For analysis of the duration of breastfeeding (BF), as well as the amount and frequency of intake of food groups, a sample of 266 infants was created, for which the inclusion criteria were age from birth to 12 months old, inclusive, as well as correctly indicated eating habit data in questionnaires.

Surveys within the study were conducted using 24-hour dietary recall for two non-successive days and a food frequency questionnaire. Only data from food frequency questionnaires were used in this study, while 24-hour dietary recall diaries were used for validation of the data. In order to evaluate the obtained data on eating habits, several guidelines developed by leading specialists were used as references, for example, WHO, EFSA, Finnish national recommendations, and German national recommendations (WHO, 2009; EFSA, 2013; National Institute for Health and Welfare in Finland, 2016; Prell and Koletzko, 2016). For analysis of the association between mother's age and age of initiation of complementary feeding or duration of $\mathrm{BF}$, the mother's age was characterised by an arithmetic average and standard deviation (SD). Analysis of variance (ANOVA) was used to compare subgroups.

Since the frequencies of consumption of different food groups and portion sizes were not normally distributed (Shapiro-Wilk test), they were indicated as median values with an interquartile range (IQR). The age was specified as an arithmetic average value with a standard deviation (SD). The Pearson's chi-squared test was used to compare proportions. A $p$ value $<0.05$ was accepted as statistically significant.

Study B was based on the methodology of Study A for collection of data on diet, and blood counts were used to determine iron metabolism, and indicators were also used.

The study intended to involve 100 infants, including equal numbers of girls and boys. The required sample size was calculated in OpenEpi, based on the expected prevalence of iron deficiency anaemia in Europe - 3\% and 2.5\% error (Hernell et al., 2015), or also based on the differences in prevalence of iron deficiency anaemia between infants who are and are not breastfed: $4 \%$ to $25 \%$ (Eussen et al., 2015). The study involved infants: aged 9-12 months old (inclusive); and birth starting from the $38^{\text {th }}$ week of gestation and with birth weight no less than $2.5 \mathrm{~kg}$. The study did not involve infants who had infectious diseases within the last two weeks; had required treatment of anaemia using medicines in the last three months; had a congenital pathology, chromosome disorders or other serious disease (for example, a transesophageal fistula, tracheomalacia, congenital heart diseases, Down syndrome, HIV, cancer); health disorders, diseases causing restrictions in the menu (for example, diagnosed food allergy, coeliac disease, etc.); known haemoglobinopathy or thalassemia; had a blood transfusion in the last six months; or parents had not signed the study consent form.

In order to determine eating habits, data from a survey of 87 respondents were obtained, and laboratory blood indicators were obtained from 65 respondents.

The data necessary for the study were collected using interviews. Two types of questionnaires were used for the interview: a food frequency questionnaire (FFQ) and 24-hour dietary recall diaries for three non-consecutive days, which were filled out within one week. Only data from 24-hour dietary recall diaries were used in this study, while FFQ were used for validation of the data. 
Blood samples were taken from infants to collect data on $\mathrm{CF}$, where parameters for determining iron metabolism, iron deficiency (ID) or iron deficiency anemia (IDA) were determined: full blood count (including mean corpuscular volume (MCV), mean corpuscular hemoglobin $(\mathrm{MCH})$, mean corpuscular hemoglobin concentration $(\mathrm{MHCH})$ ), iron, transferrin and iron-binding capacity, ferritin, and sTRs.

In order to determine the prevalence of IDA, the following indicators were determined: haemoglobin $(\mathrm{Hb})<110 \mathrm{~g} / \mathrm{l}$ (WHO, 2001) and serum ferritin (SF) below $<12 \mu \mathrm{g} / \mathrm{l}$ or $\mathrm{MCV}<74 \mathrm{fl}$ (according to the recommendations of the European Paediatric Association and WHO).

The following criteria were used to determine ID: SF 12 $\mu \mathrm{g} / \mathrm{l}$ and $\mathrm{MCV} 74 \mathrm{fl}$, and soluble transferrin receptors (sTfR) $2.4 \mathrm{mg} / \mathrm{l}$.

The Kruskal-Wallis test and the Wilcoxon-Mann-Whitney test were used in the case of continuous variables to analyse the association between eating habits and other parameters and laboratory indicators of iron metabolism. The Pearson $\chi 2$ test was used for the analysis of the same associations, but in the case of discrete variables. The frequency of consumption of different food groups and portion sizes were not normally distributed (Shapiro-Wilk test), and were indicated as median values with an interquartile range (IQR). Age was specified as an arithmetic average value with a standard deviation (SD). A $p$ value $<0.05$ was accepted as statistically significant.

The study protocol was approved by the Latvian Central Medical Ethics Commission.

\section{RESULTS}

Overall, the prevalence of boys and girls, as well as the distribution of respondents by regions, was comparable to the demographic distribution of the Latvian population.

Prevalence of BF was determined within the interval of one month (Fig. 1). Almost all infants (89\%) were breastfed in the first month of their life. When they reached the age of six months, the prevalence of $\mathrm{BF}$ reduced to $68 \%$. The number of breastfed infants reduced along with the infant's age $(p=0.002)$. The lowest indicators of prevalence of BF were observed in months 11 and 12,33\%, and 45\%, respectively.

Complementary feeding in the current sample had been initiated for 164 infants in total. The average age of initiation of complementary feeding was five months $(\mathrm{SD}=1)$. Before the age of four months, $9 \%(n=14)$ of infants received complementary food. Most parents $(85 \%)$ introduced CF for infants at the age of 4-6 months. For six percent of infants $(n=10), C F$ was introduced starting from the age of seven months. The most common choice of first $\mathrm{CF}$ was porridge (64\%) and the second most common choice of food was vegetables $(21 \%)$. The most popular vegetables were pump-

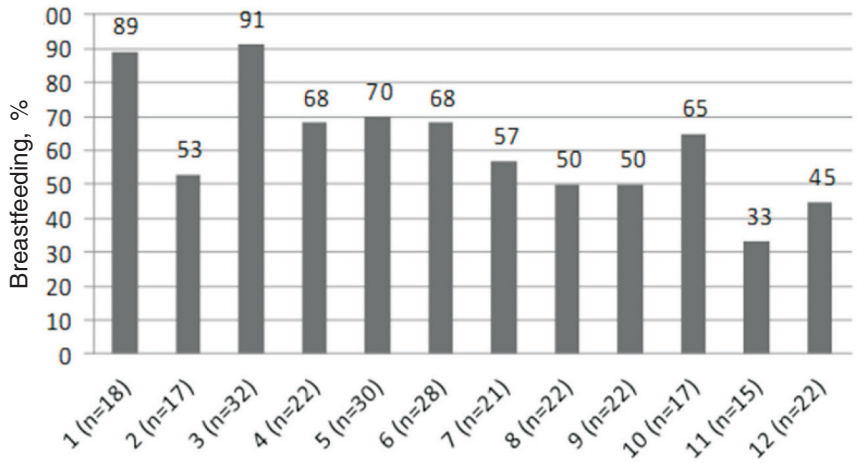

Fig. 1. Age, months (number of infants in the respective age group)

kin and potatoes. Fruit puree was chosen as the first $\mathrm{CF}$ in $10 \%$ of cases and other food in $5 \%$ of cases.

Some complementary foods were included in the menu of only a few infants before the age of four months. The biggest diversity of food was introduced at the age of 4 to 6.9 months old, and included vegetables, potatoes, fruit and berries, as well as cereals. From the age of seven months, each infant's diet included foods from nearly all food groups, such as cereals, vegetables and fruit, meat and fish, eggs, legumes, dairy products and others.

For further analysis, the infants were broken down into two groups: 0-5.9 months and 6-12.9 months. The menu of $86 \%(\mathrm{n}=126)$ of infants from the age of six months $(\mathrm{n}=$ 126) included vegetables. The average consumption was once a day and the average size of one portion was $80 \mathrm{~g}$. Vegetables were included in the menu of only $10 \%(n=12)$ of infants before the age of six months. In the vegetables group, the consumption of potatoes was analysed separately. The menu of $85 \%(n=124)$ of infants older than six months included potatoes with the average frequency of consumption being once a day. The average amount consumed per meal was $17 \mathrm{~g}$. Potatoes were included in the menu of only $8 \%(n=9)$ of infants before the age of six months.

All CF groups were included in the menu, mainly from the age of six months. The menu of infants older than six months in $81 \%(\mathrm{n}=118)$ of cases included fruit and berries. The median frequency of consumption was once a day and the median consumed amount was $54 \mathrm{~g}$ per meal. The consumption of cereals was also popular ( $88 \%)$, but its median frequency of consumption was less than once a day (six times per week), and the median amount of consumed cereals per meal was $20 \mathrm{~g}$. Meat was also introduced in the diet of most of the infants $(73 \%, \mathrm{n}=107)$. The median frequency of consumption of meat was 1.7 times a day and the portion size was $46 \mathrm{~g}$ per meal. The menu of about one-third of infants $(36 \%, \mathrm{n}=53)$ in this age group included fish. Fish consumption was relatively rare; the median frequency of consumption of fish was once a week and the amount of fish per meal was $30 \mathrm{~g}$. Consumption of milk and dairy products was rather popular among infants older than six months. Milk and dairy products were introduced in the 
menu of $66 \%(n=96)$ and $78 \%(n=114)$, respectively. The median frequency of consumption of milk was less than once a day and that of dairy products - once a day; the amount of food per meal was $45 \mathrm{ml}$ or $46 \mathrm{~g}$ of milk and $45 \mathrm{~g}$ of dairy products.

The diet of almost half of infants $(45 \%, \mathrm{n}=65)$ from the age of six included eggs; the median frequency of consumption of eggs and the median consumed amount was 1 egg per week. Consumption of legumes was less common. They were introduced in the menu of $28 \%(n=41)$ of infants in this age group. The average consumption of legumes was only once a month and the average amount per meal was $30 \mathrm{~g}$. Fats were also included in the menu of most $(73 \%, \mathrm{n}=$ $107)$ infants from the age of six months. The median frequency of consumption of fats was five times a week and the amount per meal was $6 \mathrm{~g}$.

The menu of infants younger than six months included fruit and berries in only $6 \%(n=7)$ of cases, and cereal - in $5 \%$ $(n=6)$. Meat and fish were introduced in the menu of only some infants (3\%, $\mathrm{n}=3$ and $1 \%, \mathrm{n}=1$, respectively).

Milk and dairy products were introduced in the menu of $3 \%$ $(\mathrm{n}=3)$ of infants younger than six months. The menu of only $1 \%(n=1)$ of infants of this age included legumes and the menu of $3 \%(n=4)$ included fats.

Overall, 73 respondents from different Latvian regions participated in Study B. There was a similar distribution among girls and boys, $56 \%$ and $44 \%$, respectively. Unlike as in Study A, most of the respondents in the sample for this study were from cities other than Rìga, amounting to almost half or $44 \%$. Most of the mothers were aged 26 to 35 years old (75\% in the study B and $58 \%$ in study A). The level of education of mothers in both studies was almost identical, and higher education dominated in both.

The nutrition data analysis showed that iron was consumed in the amount of $7.4 \mathrm{mg}$ per day on average (median $=6.5$ $\mathrm{mg} /$ day). Only $38 \%$ of infants $(\mathrm{n}=27)$ consumed the recommended $8 \mathrm{mg}$ of iron per day or more.

Iron with products of animal origin was consumed in the amount of $13 \%$ of the total intake of iron with food. A detailed analysis showed that less than $10 \%$ of the iron was taken up through products of animal origin for $35 \%(\mathrm{n}=25)$ of respondents, $10-20 \%$ was taken up by $39 \%(n=28)$ of infants, and $20 \%$ or more by $26 \%(\mathrm{n}=19)$ of infants. It should be noted that of the total consumed meat, red meat constituted $56 \%$, poultry $-35 \%$, sausages $-9 \%$, and offal $-1 \%$.

$21 \%(n=15)$ of respondents followed the exclusive BF recommendations - to continue BF for the first six months of life; $29 \%(\mathrm{n}=21)$ of infants were breastfed from 4 to 5.9 months, and less than half $(40 \%(n=29))$ of the respondents did not breastfeed or breastfed infants for less than four months.
In response to the questions about $\mathrm{BF}$ at the time of the survey, $44 \%(\mathrm{n}=32)$ of infants received breast milk, while $53 \%(\mathrm{n}=39)$ of infants received infant milk formula.

The average age of initiation of complementary feeding was five months ( $\mathrm{SD}=1)$, as in study A. Before the age of four months, only one infant $(1 \%)$ received complementary food. Most of the parents $(93 \%, \mathrm{n}=64)$ introduced CF for infants at the age of $4-6$ months. For $6 \%$ of infants $(n=4), C F$ was introduced starting from the age of seven months.

At the time of the survey, cow's milk was introduced for $38 \%$ of infants, while meat for $34 \%$ of infants at the age of 4-6 months old, and for 53\% at the age after seven months old.

An important fact was that $79 \%$ of mothers used iron medicines during pregnancy.

Iron deficiency was found in 9.6\% $(\mathrm{n}=7 ; 95 \%$ TI: $4.7-18.5 \%$ ) of infants and iron deficiency anaemia in $4.1 \%$ of infants ( $\mathrm{n}=3$; $95 \%$ TI: $1.4-11.4 \%)$.

Overall, more than a half of the infants showed iron metabolism indicators within normal limits: MCV, SF, iron and haemoglobin. However, only $36 \%(n=26)$ had their sTfR within normal limits. An increased level of sTfr in blood might be evidence of reduced iron reserves in the body.

$\mathrm{MCV}, \mathrm{SF}$, iron, iron binding capacity, sTfR, and $\mathrm{Hb}$ were used as the main laboratory indicators of iron metabolism. Exclusive BF, the use of infant formulae, cow's milk, legumes and meat, and general intake of products of animal origin were considered as main nutritional factors when studying the association with iron metabolism.

Among continuous variables, BF had the biggest association with iron metabolism. The association of exclusive BF and $\mathrm{BF}$ with the following iron metabolism indicators was observed: iron, MCV and SF.

The level of iron in the blood of the infants who did not receive breast milk at the time of the survey was higher (10.7 $\mu \mathrm{mol} / \mathrm{l}, \mathrm{n}=30, \mathrm{IQR}=5.7$ ) than in those who were breastfed $(8.5 \mu \mathrm{mol} / \mathrm{l}, \mathrm{n}=26, \mathrm{IQR}=3.1)(p=0.0125)$. A similar association with exclusive $\mathrm{BF}$ was also observed for SF, where the level of SF was higher in infants who were not exclusively breastfed or were breastfed for a short period of time $(p=0.0042)$. A lower level of SF was observed in infants who were breastfed at the time of the survey ( $p=$ 0.0010). On the opposite side, the level of SF was higher in infants who received an infant milk formula $(p=0.0157)$ (Table 1).

An association of exclusive BF with MCV was observed, where the infants who were not exclusively breastfed for at least four months had lower MCV compared to not exclusively breastfed for at least four months: MCV $76 \mathrm{fl}(\mathrm{n}=$ 31 , IQR 7.2) and $81 \mathrm{fl}(\mathrm{n}=22$, IQR 4$)(p=0.0116)$, respectively. 
Table 1. Association of SF (ng/ml) with exclusive BF, BF, and use of infant formulae

\begin{tabular}{|c|c|c|c|c|}
\hline \multicolumn{2}{|c|}{ Parameter } & \multirow{2}{*}{$\begin{array}{c}\begin{array}{c}\text { Median } \\
\mathrm{ng} / \mathrm{ml}\end{array} \\
29.5\end{array}$} & \multirow{2}{*}{$\begin{array}{c}\mathrm{IQR} \\
\mathrm{ng} / \mathrm{ml}\end{array}$} & \multirow{2}{*}{$\begin{array}{l}\mathrm{n} \\
24\end{array}$} \\
\hline $\begin{array}{l}\text { Was the child exclusively } \\
\text { breastfed at least until the } \\
\text { age of } 4 \text { months? }\end{array}$ & $\begin{array}{l}\text { Was not exclusively } \\
\text { breastfed for at least } \\
4 \text { months }\end{array}$ & & & \\
\hline & $\begin{array}{l}\text { Was exclusively } \\
\text { breastfed for at least } \\
4 \text { months }\end{array}$ & 17.8 & 14.3 & 31 \\
\hline \multirow{2}{*}{$\begin{array}{l}\text { Was the child breastfed } \\
\text { during the survey? }\end{array}$} & Is not breastfed & 30.5 & 22.9 & 30 \\
\hline & Is breastfed & 16.1 & 10.7 & 27 \\
\hline \multirow{2}{*}{$\begin{array}{l}\text { Is the child fed with an } \\
\text { infant milk formula } \\
\text { during the survey? }\end{array}$} & $\begin{array}{l}\text { Is not fed with a for- } \\
\text { mula }\end{array}$ & 17.8 & 17.3 & 27 \\
\hline & $\begin{array}{l}\text { Is fed with } \\
\text { a formula }\end{array}$ & 26.2 & 25.9 & 33 \\
\hline
\end{tabular}

The introduction of cow's milk in the diet was associated with the level of iron in the blood $(p=0.0171)$. Iron in blood was within normal limits in almost all $(\mathrm{n}=30,94 \%)$ infants whose diet did not include cow's milk and was lower in $30 \%(n=8)$ of the infants in whose diet cow's milk had already been introduced. When analysing as a continuous variable, it was observed that the level of iron in the blood was lower in infants whose diet included cow's milk $(8.3 \mu \mathrm{mol} / \mathrm{l}, \mathrm{n}=27, \mathrm{IQR} 5.5)$, compared to infants without cow's milk in the $\operatorname{diet}(10.3 \mu \mathrm{mol} / \mathrm{l}$, IQR $4.8, \mathrm{n}=$ 32) $(p=0.0234)$

An association was observed between the level of SF in blood and intake of legumes. The level of SF was within normal limits in most $(93 \%, \mathrm{n}=26)$ infants whose diet did not include legumes, and to a lesser extent in those whose diet included legumes $-72 \%(\mathrm{n}=21)(p=0.0425)$.

For infants who received iron predominantly from nonanimal products, SF was within the normal range in $100 \%$ $(\mathrm{n}=20)$ of infants receiving $10 \%$ iron from animal foods, $78 \%(\mathrm{n}=18)$ receiving $10-20 \%$ and $71 \%(\mathrm{n}=12)$ receiving $20 \%$ iron from animal foods $(p=0.0405)$.

Contradictory results were observed in the association of the level of $\mathrm{Hb}$ in blood with the intake of iron with products of animal origin. A lower amount of iron consumed with products of animal origin was associated with a higher level of $\mathrm{Hb}$ observed in blood $(p=0.0188)$ (Table 2).

Contradictory data were also been obtained for the association with iron binding capacity. The highest level of iron binding capacity $(80 \mu \mathrm{mol} / \mathrm{l}, \mathrm{n}=13, \mathrm{IQR}=10)$ was observed when infants received 150-250 g of products of animal origin per day, while it was lower $(74 \mu \mathrm{mol} / \mathrm{l}, \mathrm{n}=14$, $\mathrm{IQR}=12$ ) when less than $150 \mathrm{~g}$ of products of animal origin per day, or more than $250 \mathrm{~g}$ per day $(70 \mu \mathrm{mol} / \mathrm{l} ; \mathrm{n}=21$; IQR = 7), were consumed ( $p=0.0436)$.

The observations confirmed that the use of iron medicines during pregnancy has an association with MCV. The strongest association ( $p=0.0061)$ was observed, if iron medicines
Table 2. Association of $\mathrm{Hb}$ in blood sample with intake of iron with products of animal origin

\begin{tabular}{l|c|c|c}
\hline $\begin{array}{c}\text { What share in the total amount of consumed } \\
\text { iron was taken with products of animal } \\
\text { origin? }\end{array}$ & $\begin{array}{c}\text { Median } \\
\mathrm{g} / \mathrm{l}\end{array}$ & $\begin{array}{c}\mathrm{IQR} \\
\mathrm{g} / \mathrm{l}\end{array}$ & $\mathrm{Nn}$ \\
\hline Less than $10 \%$ & 124 & 10 & 21 \\
$10-19 \%$ & 117 & 10 & 25 \\
$20 \%$ or more & 118.5 & 12 & 18
\end{tabular}

were used during pregnancy or after giving birth. MCV was within normal limits in $84 \%(n=43)$ of the infants whose mothers used iron medicines, while MCV was lower in $63 \%$ $(\mathrm{n}=5)$ of infants whose mothers did not use iron medicines $(p=0.0061)$.

It was revealed that STfR was within normal limits in $62 \%$ $(\mathrm{n}=18)$ of infants who were first-born children, and only in $32 \%(\mathrm{n}=8)$ in infants who were not first-born children $(p=$ 0.0275) (Table 2). An association was found between the order of birth of the child and sTfR and iron binding capacity. First-born children had a lower level of sTfR $(1.7 \mathrm{mg} / \mathrm{l}$, $\mathrm{n}=29, \mathrm{IQR}=0.5 \mathrm{mg} / \mathrm{l}$ ) and higher iron binding capacity in their blood sample compared to not first child (sTfR level $1.8 \mathrm{mg} / \mathrm{l}, \mathrm{n}=25, \mathrm{IQR}=0,5 \mathrm{mg} / \mathrm{l}) \quad(p=0.0179)$.

\section{DISCUSSION}

Healthy eating habits of infants should start with breast feeding. According to the recommendations of the WHO and the Latvian Ministry of Health, exclusive BF should continue for the first six months, and then $\mathrm{CF}$ should be introduced combining it with $\mathrm{BF}$, and $\mathrm{BF}$ should continue up to the age of two years (WHO, 2009; Ministry of Health, 2003). The results of this study showed that $89 \%$ of mothers living in Latvia started BF infants in the first month of their life. Most mothers continue BF in the first half of a year of life in Nordic countries: Finland (58\%), Sweden $(63 \%)$, Latvia (68\%), Iceland (74\%) and Norway (80\%) (Hornell et al. 2013). The BF indicator until the age of six months old is the highest in Latvia among the Baltic states: $31 \%$ in Lithuania and 40\% in Estonia (Save the Children, 2012). The duration of BF has improved, if we compare these results with the latest published data. The initiation of breastfeeding of newborns has reduced from $94 \%$ to $89 \%$, but breastfeeding until the age of six months, in accordance with the data provided by surveyed persons, has increased from $58 \%$ to $63 \%$, and until the age of 12 months old from $39 \%$ to $45 \%$ (Oginska, 2008).

Regarding the recommended duration of exclusive breastfeeding, contradictions are observed in the results of several studies. Until 2001, WHO recommended to continue exclusive breastfeeding in the first four to six months (Fewtrell et al., 2007). A systematic review of literature leads one to the conclusion that this opinion has changed, and since 2001 it has been recommended to continue exclusive breastfeeding in the first six months of life (Kramer and Kakuma, 2002; WHO and UNICEF, 2003). In 2004 and 2012, systematic 
reviews of literature on the optimal duration of exclusive breastfeeding showed that exclusive breastfeeding should continue in the first six months, but regarding iron intake the reviewed studies were contradictory, and one of the conclusions was that the level of iron in infants in emerging countries was lower (Kramer, 2002; Kramer and Kakuma, 2004). The Latvian Ministry of Health also recommends continuation of BF in the first six months of life (Ministry of Health, 2003). In the present study, $21 \%$ of the respondents followed the recommendation for exclusive breastfeeding, but a slightly less than half $(40 \%(n=29))$ did not breastfeed at all or breastfeed for less than four months.

There are different opinions about the age of initiation of complementary feeding, and therefore, recommendations also vary. The Latvian national nutrition recommendations have been developed in accordance with WHO guidelines, where the initiation of complementary feeding is recommended from the age of six months, starting with a small amount of food and increasing it as the child becomes older (WHO, 2009; Dewey, 2013; Ministry of Health 2003). EFSA indicates that CF should be initiated in infants not earlier than at the age of four months and no later than at the age of six months (EFSA, 2013). EFSA recommendations match the latest recommendations of Finland. The German recommendations on infant nutrition specify that starting from the age of 4-5 months most infants are capable of taking CF (Prell and Koletzko, 2016). Similar results with regard to the age of introduction of CF can be found in an Italian study, where $\mathrm{CF}$ for infants was initiated at the age of four to six months, $34.2 \%$ and $85.5 \%$, respectively (Giovannini et al., 2004). The results of both studies (A and B) showed that CF for infants was mainly initiated at the age of four to six months, in $85 \%$ and $93 \%$ of cases, respectively.

The guidelines express a single opinion in relation to the introduction of vegetables in the diet and state that vegetables should be one of the first foods to be introduced as complementary food. The study showed that vegetables and potatoes are a very popular choice of food, and they are introduced into food after reaching the age of six months. Also, fruits and berries are eaten by $81 \%$ of infants older than six months on a regular basis. The recommendations in Latvia provide that fruit and berries may be introduced at the same time as vegetables (Ministry of Health, 2003). Such recommendations are supported by the Finnish nutrition guidelines (National Institute for Health and Welfare in Finland, 2016).

WHO, Finnish, and Latvian nutrition guidelines provide that porridge may be chosen as one of the first components of CF (WHO, 2009; National Institute for Health and Welfare in Finland, 2016; Ministry of Health, 2003). The EFSA and German nutrition guidelines recommend starting porridge after the first $\mathrm{CF}$ has been introduced in the diet (EFSA, 2013; Prell and Koletzko, 2016). This study showed that cereals are consumed mainly after six months of age, and used less than once a day in the amount of $20 \mathrm{~g}$ per meal. This might be too little.
Cow's milk is not recommended for use by children before they reach the age of one year (Department of Education and Early Childhood Development, 2014; Ministry of Health, New Zealand, 2008; Crawley and Westland, 2015). However, the ESPGHAN indicates that small amounts of cow's milk and milk alternatives may be introduced after iron-fortified products have been included in the menu. Early introduction of cow's milk and its use in amounts exceeding $500 \mathrm{ml}$ is related to the development of iron deficiency in the body (Agostoni et al., 2008). 66\% of infants consume cow's milk in Latvia before they reach the age of one year; however, it is used less than once a day, including $45 \mathrm{ml}$ of milk in one meal. Fermented dairy products are mainly introduced after six months of age (78\% of infants). In accordance with Latvian nutrition recommendations, dairy products should only be introduced into the infants' diet after they reach the age of one year (Ministry of Health, 2003). Finnish recommendations state that dairy products may be introduced starting from the age of ten months old (National Institute for Health and Welfare in Finland, 2016). Other recommendations do not include clear instructions regarding the use of dairy products.

Meat is an important source of haem iron, where iron is inherently of high bioavailability compared to sources of non-haem iron, which can be found in meat alternatives (for example, legumes), as well as iron-fortified cereals (Critch, 2014). The present study on the introduction and use of meat in infants provides good results. Meat is introduced into the diet of children in $73 \%$ of cases, when they reach the age of six months, and later its consumption per meal increases considerably when calculated per meal, reaching intake of almost twice a day. According to the WHO and the Pan American Health Organization, "meat, poultry, fish or eggs should be eaten daily or as often as possible" to satisfy the child's need for nutrients (WHO and Pan American Health Organization, 2003). The Latvian recommendations provide that meat should be introduced at the age of eight months (Ministry of Health, 2003). Intake of fish is recommended by replacing fish with meat once or twice a week, but fish is only consumed by $36 \%$ of children after they reach the age of six months, and this is done once a week.

In accordance with Latvian recommendations, eggs should only be introduced after children reach the age of one year. These study results show that eggs are consumed after infants reach the age of six months, and $45 \%$ of children eat one egg per week. Contrary to the Latvian recommendations, WHO and Finnish nutrition guidelines permit the intake of eggs before infants reach the age of one year (WHO, 2009; Ministry of Health, 2003; National Institute for Health and Welfare in Finland, 2016).

The reviewed guidelines do not describe the intake of legumes, unlike Latvian nutrition guidelines that indicate that legumes may be introduced at the age of eight months (Ministry of Health, 2003). This study showed that only $28 \%$ of infants who are six months old or older consume legumes, and they do this rarely and in small amounts. 
Prevalence of iron deficiency and iron deficiency anaemia in infants in emerging countries and in developed countries is still recognised as an important issue. The systematic review of literature confirmed that iron deficiency is a common problem in European countries and is found in $2 \%$ to $25 \%$ of infants aged 6-12 months (Eussen et al., 2015). The authors mention the association of iron deficiency with several eating habits such as: intake of cow's milk, ironfortified foods as complementary food, red meat, fruit and vegetables. Iron deficiency anaemia is mainly below 5\% in Nordic countries and Western Europe, while it reaches up to $50 \%$ in some countries and populations in Eastern Europe. Similarly as in Latvia, up to $50 \%$ of infants also do not receive the recommended dose of iron in most countries France, Germany, Iceland, Netherlands, Poland, Spain, Sweden, United Kingdom (Eussen et al., 2015).

Statistically significant results confirmed that infants who were exclusively breastfed had a lower level of SF and MCV in blood, which might suggest early iron metabolism disorders. A cohort study on related risk factors for exclusively breastfed infants, using $\mathrm{Hb}$ and $\mathrm{SF}$ as iron metabolism indicators, showed that the number of infants at age 6 months with ID has grown by more than four times, reaching $26.1 \%$, where IDA was found in $23.9 \%$ of infants (Rosa et al., 2014).

The association between the duration of exclusive breastfeeding and iron deficiency was also described in a study conducted in Bolivia. The results showed that infants who were breastfed for four months or longer had a strong association with iron deficiency, but not anaemia. The level of iron and $\mathrm{Hb}$ was considerably lower with increased duration of exclusive breastfeeding (Burke et al., 2018). A statistically significant association with iron and SF was found - the level of iron and SF was higher in infants who did not receive breast milk. A study in China showed that breastfeeding had a significant association with iron metabolism $(p<0.001)$. The authors have concluded that the risk of ID and IDA is higher in infants who receive breast milk or mixed feeding. Although favourable effects of breastfeeding cannot be doubted, the authors emphasise that it may cause risk of ID and therefore, guidelines for the determination and prevention of iron deficiency and anaemia are necessary (Clark et al., 2017). Similar results are described by Korean authors where the infants who were exclusively breastfed, iron deficiency was observed in $52.9 \%$ and anaemia in $28.3 \%$ of cases; in those infants who received both breast milk and infant milk formula, ID was observed in $10.1 \%$ and IDA - in $4.2 \%$, while who received infant milk formulae, ID and IDA were observed in 3\% and $0 \%$, respectively $(p<0.001)$ (Hong et al., 2017).

The present revealed association between the consumption of cow's milk and reduced level of iron in the blood, as well as an association with sTfR, which was increased in infants for whom the intake of cow's milk had already been initiated. The systematic review of literature and meta-analysis confirm the negative impact of cow's milk on iron metabolism in infants and young children, as the intake of cow's milk by infants is related to increased risk of iron deficiency (Griebler et al., 2016).

The study results showed that the introduction of meat was associated with the level of $\mathrm{Hb}$ in blood. Interestingly, in infants for whom intake of meat was introduced at an early stage, at the age of 4-6 months, the level of $\mathrm{Hb}$ was reduced in $20 \%$ of cases and within normal limits in $80 \%$ of infants, respectively. Another intervention study revealed an association between the use of meat and $\mathrm{Hb}$ level. The results of that study suggested that depending on the amount of meat in the diet, the HB level in blood changed considerably ( $p=$ 0.008). However, no significant difference was observed in SF and Tfr indicators, as in our this study (Engelmann et al., 1998). These research results did not show an association between the frequency or amount of intake of meat and iron metabolism indicators in the blood. Furthermore, another prospective cohort study studied whether more meat in the diet of children aged 4 to 24 months old would improve the metabolism of iron and other microelements in the body. A considerable association was observed in infants at the age of 12 months old between SF and meat intake $(p<0.023)$. A trend for an inverse association between $\mathrm{Hb}$ concentration and the intake of meat was observed in the same age group $(p<0.068)$ (Taylor et al., 2004).

A similar cross-sectional study was conducted in Jerusalem. The results of this survey showed that ID was observed four times more often in the group where children consumed very little meat than in children who consumed it two or more times per week ( $p=0.023)$. However, such an association with iron deficiency was not observed in the case of use of poultry. It was also concluded that iron deficiency is related to the insufficient intake of red meat. Developed countries consume poultry much more often than red meat, which may become a risk factor for iron deficiency and increase its prevalence (Moshe et al., 2013). A randomised double-blind controlled study in Germany was conducted to determine whether the low content of meat in complementary food, which is accepted by European Union law, may increase the risk of iron deficiency in the period of complementary feeding in infants receiving adequate nutrition. In the group of healthy infants, who were breastfed or fed with infant milk formula and received complementary food in accordance with nutritional recommendations, average iron metabolism biomarker indicators were within normal limits before (four months), during (seven months) and after (ten months) the involvement with different amounts of consumed meat. No significant differences in biomarkers were found between the groups where meat was consumed in increased and low amounts as might be expected. This study did not reveal any difference in the intake of iron with food between high and low meat consumption groups. The researchers emphasised that the most important discovery was that after the primary data analysis, no justified evidence of disturbed iron metabolism was found for infants receiving meat as complementary food in lower amounts than recommended by the European Union. However, secondary analysis of data showed that such a small amount of meat in the 
diet of many infants consuming breast milk in the first four to six months of their life in accordance with recommendations may increase the risk of iron metabolism disorders in the second half of the first year of their life (Dube et al., 2010).

Although infants living in Latvia do not consume legumes in large amounts, their use has shown statistically significant associations with iron metabolism. The intake of legumes was associated with a lower the level of SF in blood. This might be explained by the high content of phytates in legumes, which bind to iron and thus delay its absorption by the child's body (Gibson et al., 2010; Dewey, 2013; Lim et al., 2015).

Although eating habits are very important in the prevention of iron deficiency, it is important to study not only the impact of nutrition, but also the potential association of other factors with iron metabolism in infants. This study examined the association of iron deficiency with the use of iron medication during pregnancy or after giving birth, the mother's age, mother's education and the order of birth of the child. Statistically significant results were only found for the association of the order of birth of the child and sTfR, where sTfR in first-born infants was within normal limits in more infants $(62 \%)$ compared to those who were not first-born $(32 \%)$.

Based on the data of this study as well as when examining the results of other studies, it is important to consider and study the association with the mother's age, the order of birth of the child, mother's nutrition and mother's health condition (Marques et al., 2016), mother's education, socioeconomic condition of the family (Thane et al., 2000), infant's sex (Soh et al., 2004), infant's weight, including excessive weight, obesity and other factors (Cox et al., 2016; Soh et al., 2004).

\section{CONCLUSIONS}

1. Eating habits of infants living in Latvia partially correspond to the guidelines of the Latvian Ministry of Health: diversity of food is observed, complementary feeding is initiated at the recommended age, cow's milk is not used in amounts exceeding $600 \mathrm{ml}$ per day, and meat is introduced in the diet in a timely manner and in sufficient amounts. However, only $21 \%$ follow the exclusive BF recommendation.

2. $63 \%$ of infants at the age of 9-12 months do not consume a sufficient amount of iron with food and ID was observed in this group in $9.6 \%$ of infants, while IDA in $4.1 \%$ of infants.

3. Associations with the following eating habits at an early age and other factors that affected iron metabolism in a favourable were found: a higher level of SF in the blood was observed in infants who received an infant milk formula; a normal level of SF in the blood was observed in infants who consumed iron with food at least in the recommended dose
(8 mg); a normal MCV level in the blood in the second half of the first year of life was observed in mothers who used iron medicines during pregnancy and after giving birth.

4. Associations with the following eating habits at an early age and other factors that affected iron metabolism in an unfavorable way were as follows. A lower level of iron in the blood was observed in infants for whom cow's milk was introduced at an early stage; a lower MCV level was also observed in those infants whose exclusive breastfeeding continued for at least the first four months of life compared to infants who were not exclusively breastfed for at least four months; a lower SF was observed in those infants who were breastfed and whose exclusive breastfeeding continued for at least the first four months of life, as well as in those infants in whose diet legumes have been introduced; a lower level of iron in the blood was observed in infants who were breastfed; a higher level of sTfR in the blood was observed in infants who were not first-born compared to those who were first-born.

\section{REFERENCES}

Agostoni, C., T. Decsi, M. Fewtrell, O. Goulet, O., Kolacek, S., Koletzko, B., Michaelsen, K. F., Moreno, L., Puntis, J., Rigo, J. (2008). Complementary feeding: A commentary by the ESPGHAN Committee on Nutrition. $J$. Pediatr. Gastroenterol. Nutr., 46 (1), 99-110.

Baker, R. D.; Greek, F. R. (2010). Diagnosis and prevention of iron deficiency and iron-deficiency anemia in infants and young children ( $0-3$ years of age). Pediatrics, 126 (5), 1040-1050.

Michaelsen, F. K., Weaver, L., Branca, F., Robertson, A. (2000). Feeding and nutrition of infants and young children: Guidelines for the WHO European Region, with emphasis on the former Soviet countries; World Health Organization. Regional Office for Europe. Copenhagen: WHO Regional Office for Europe. https://apps.who.int/iris/handle/10665/272658 (accessed 17.12.2021)

Cox, K. A., Parkin, P., Anderson, L., Chen, Y., Birken, C., Maguire, J., Macarthur, C., Borkhoff, C., TARGet Kids! Collaboration. (2016). Association between meat and meat-alternative consumption and iron stores in early childhood. Acad. Pediatr., 16 (8), 783-791.

Crawley, H., Westland, S. (2019). Infant milks in the UK: A practical guide for health professionals.

https://nhsforthvalley.com/wp-content/uploads/2019/04/Infant-Milks_February19_final_updated.pdf (accessed 17.12.2021).

Critch, J. N. et al. (2011). Nutrition for healthy term infants: Recommendations from six to 24 months. Canad. J. Diet. Pract. Res., 75 (2), 107.

Dewey, K. (2013). The challenge of meeting nutrient needs of infants and young children during the period of complementary feeding: An evolutionary perspective. J. Nutr., 143 (12), 2050-2054.

Dube, K., Schwartz, J., Mueller, M., Kalhoff, H., Kersting, M. (2010). Complementary food with low (8\%) or high (12\%) meat content as source of dietary iron: A double-blinded randomized controlled trial. Eur. J. Nutr., 49 (1), 11-18

EFSA (2009). General principles for the collection of national food consumption data in the view of a pan-European dietary survey. EFSA J., 7 (12), 1435

EFSA (2010). Scientific opinion on dietary reference values for fats, including saturated fatty acids, polyunsaturated fatty acids, monounsaturated fatty acids, trans fatty acids, and cholesterol. EFSA J., 8 (3), 1461.

EFSA Panel on Dietic Products (2009). Scientific opinion on the appropriate age for introduction of complementary feeding of infants. EFSA J., 7 (12), 1423. 
EFSA (2010). Results of the monitoring of dioxin levels in food and feed. EFSA J., 8 (3), 1385.

EFSA (2010). Update on acrylamide levels in food from monitoring years 2007 to 2010. EFSA J., 10 (10), 2938.

EFSA (2011). Update on furan levels in food from monitoring years 2004-2010 and exposure assessment. EFSA J., 9 (9), 2347.

EFSA (2013). Scientific opinion on nutrient requirements and dietary intakes of infants and young children in the European Union. EFSA J., 11 (10), 3408 .

Engelmann, M. D., Sandstrom, B., Michaelsen, K. F. (1998). Meat intake and iron status in late infancy: An intervention study. J. Pediatr. Gastroenterol. Nutr., 26 (1), 26-33.

Erkkola, M., Kyttälä, P., Takkinen, H.-M., Kronberg-Kippilä, C., Nevalainen, J., Simell, O., Ilonen, J., Veijola, R., Knip, M., Virtanen, S. M. (2011). Nutrient intake variability and number of days needed to assess intake in preschool children. Brit. J. Nutr., 106 (1), 130-140.

Eussen, S., Alles, M., Uijterschout, L., Brus, F., Horst-Graat, J. (2015). Iron intake and status of children aged 6-36 months in Europe: A systematic review. Ann. Nutr. Metab., 66 (2-3), 80-92.

Fewtrell, M., Bronsky, J., Campoy, C., Domellöf, M., Embleton, N., Fidler Mis, N., Hojsak, I., Hulst, J. M., Indrio, F., Lapillonne, A., Molgaard, C. (2017). Complementary feeding: A position paper by the European Society for Paediatric Gastroenterology, Hepatology, and Nutrition (ESPGHAN) Committee on Nutrition. J. Pediatr. Gastroenterol. Nutr., 64 (1), 119-132.

Gibson, R. S., Bailey, K. B., Gibbs, M., Ferguson, E. L. (2010). A review of phytate, iron, zinc, and calcium concentrations in plant-based complementary foods used in low-income countries and implications for bioavailability. Food Nutr. Bull., 31 (2_suppl2), S134-S146.

Giovannini, M., Riva, E., Banderali, G., Scaglioni, S., Veehof, S. H., Sala, M., Radaelli, G., Agostoni, C. (2004). Feeding practices of infants through the first year of life in Italy. Acta Pcediatr., 93 (4), 492-497.

Griebler, U., Bruckmüller, M. U., Kien, C., Dieminger, B., Meidlinger, B., Seper, K., Hitthaller, A., Emprechtinger, R., Wolf, A., Gartlehner, G. (2016). Health effects of cow's milk consumption in infants up to 3 years of age: A systematic review and meta-analysis. Public Health Nutr., 19 (2), 293-307.

Hernell, O., Fewtrell, M. S., Georgieff, M. K., Krebs, N. F., Lönnerdal, B. (2015). Summary of current recommendations on iron provision and monitoring of iron status for breastfed and formula-fed infants in resource-rich and resource-constrained countries. J. Pediatr., 167 (4), Suppl., 40-47.

Hörnell, A., Lagström, H., Lande, B., Thorsdottir, I. (2013). Breastfeeding, introduction of other foods and effects on health: A systematic literature review for the $5^{\text {th }}$ Nordic nutrition recommendations. Food Nutr. Res. (April), 57.

Kramer, M. S., Kakuma, R. (2012). Optimal duration of exclusive breastfeeding. Cochrane Pregnancy and Childbirth Group. Cochrane Database Syst. Rev., 15 (8), CD003517.

Lim, K., Booth, A., Szymlek-Gay, E. A., Gibson, R. S., Bailey, K. B., Irving, D., Nowson, C., Riddell, L. (2015). Associations between dietary iron and zinc intakes, and between biochemical iron and zinc status in women. $\mathrm{Nu}$ trients, 7 (4), 2983-2999.

Ministry of Health. Food and Nutrition Guidelines for Healthy Infants and Toddlers (aged 0-2) A background paper. (2008).

ht tps://www.moh.govt.nz/notebook/nbbooks.nsf/0/ 1CB71808F8E129AFCC2574520008337D/\$file/0-2-food-and-nutritionguidelines-may08.pdf (accessed 04.03.2014).

Moshe, G., Amitai, Y., Korchia, G., Korchia, L., Tenenbaum, A., Rosenblum, J., Schechter, A. (2013). Anemia and iron deficiency in children: As- sociation with red meat and poultry consumption. J. Pediatr. Gastroenterol. Nutr., 57 (6), 722-727.

National Centre for Health (2001). Healthy people 2000: national health promotion and disease prevention objectives: healthy people 2000 final review. Hyattsville, Md., Dept. of Health and Human Services, Centers for Disease Control and Prevention, National Center for Health Statistics. https://www.cdc.gov/nchs/data/hp2000/hp2k01.pdf (accessed 04.03.2014)

National Health and Medical Research Council (2012). Eat for health: Infant Feeding Guidelines Information for health workers. National Health and Medical Research Council. https://www.eatforhealth.gov.au/sites/default/files/files/the_guidelines/n56_infant_feeding_guidelines.pdf (accessed 20.03.2014).

National Institute for Health and Welfare in Finland. (2016). Eating Together — food recommendations for families with children. http://www.julkari.fi/handle/10024/130435 (accessed 505.04.2019).

Oginska, A., Vētra J., Pilmane M. (2008). Relations between infant feeding practices and anthropometrical traits in Latvia. Acta Med. Lit., 15, 61-66.

Prell, C., Koletzko, B. (2016). Breastfeeding and complementary feeding. Dtsch. Arztebl. Int., 113 (25), 435-444.

Save the Children (2012). Nutrition in the first 1,000 days. https://www.savethechildren.org/content/dam/usa/reports/advocacy/ sowm/sowm - 2012.pdf (accessed 05.06.2015).

Soh, P., Ferguson, E. L., McKenzie, J. E., Homs, M. Y., Gibson, R. S. (2004). Iron deficiency and risk factors for lower iron stores in 6-24- month-old New Zealanders. Eur. J. Clin. Nutr., 58 (1), 71-79.

Thane, C. W., Walmsley, C. M., Bates, C. J., Prentice, A., Cole, T. J. (2000). Risk factors for poor iron status in British toddlers: Further analysis of data from the National Diet and Nutrition Survey of children aged 1.5-4.5 years. Public Health Nutr., 3 (4), 433-440.

Vaivada, T., Gaffey, M. F., Bhuta, Z. A. (2017). Promoting early child development with interventions in health and nutrition: A systematic review. Pediatrics, 140 (2), e20164308.

Veselības ministrija (Ministry of Health) (2003). Veselīga uztura ieteikumi zīdaiņu barošanai [Healthy dietary tips for infants].

https://www.spkc.gov.lv/lv/veseliga-uztura-ieteikumi/uzturs_zidainiem1.pdf (accessed 20.04.2019).

Veselības ministrija (Ministry of Health) (2017). Ieteicamās enerǵijas un uzturvielu devas Latvijas iedzīvotājiem [Recommended doses of energy and nutrients for the population of Latvia]. https://www.spkc.gov.lv/lv/me$\mathrm{dia} / 2839 /$ download (accessed 02.05.2019).

World Health Organization (2009). WHO Guidelines Approved by the Guidelines Review Committee. In: Infant and Young Child Feeding: Model Chapter for Textbooks for Medical Students and Allied Health Professionals. https://apps.who.int/iris/handle/10665/44117 (accessed 17.12.2021).

Joint World Health Organization/Centers for Disease Control and Prevention Technical Consultation on the Assessment of Iron Status at the Population Level (2004). Assessing the iron status of populations: including literature reviews: report of a Joint World Health Organization/Centers for Disease Control and Prevention Technical Consultation on the Assessment of Iron Status at the Population Level.

https://apps.who.int/iris/handle/10665/75368 (accessed 17.12.2021).

World Health Organization (2011). Maternal, newborn, child and adolescent health. https://apps.who.int/iris/handle/10665/44873 (accessed 23.06.2015)

World Health Organization (2001). Iron deficiency anaemia: assessment, prevention and control. https://apps.who.int/nutrition/publications/micronutrients/anaemia_iron_deficiency/WHO_NHD_01.3/en/index.html (accessed 05.07.2015). 


\section{AGRĪNIE UZTURA PARADUMI ZĪDAIN̦IEM UN TO SAISTĪBA AR DZELZS VIELMAIN̦U}

Pirmajā dzīves gadā notiek ḷoti strauja augšana un attīstība. Pētījuma mērḳis bija izpētīt Latvijas zīdaiņu agrīnos uztura paradumus un to saistību ar dzelzs metabolismu. Pētījums sastāv no A $(n=344)$ un B $(n=73)$ dạ̦ām. Gandrīz visi zīdaiņi $(89 \%)$ bija zīdīti pirmajā dzīves mēnesī, un pirmos sešus mēnešus $21 \%(\mathrm{n}=15)$. Vidējais papilduztura ieviešanas vecums bija pieci mēneši. Dzelzi ar uzturu uzṇēma vidēji 7,4 mg dienā. Dzelzs deficīts (DD) bija 9,6\% ( $\mathrm{n}=7$ ) un dzelzs deficīta anēmija (DDA) - 4,1\% ( $=3$ ). Dzelzs līmenis asinīs bija samazināts 30\% ( $n=8)$ zīdaiņu, kuri saṇēma govs pienu. Zīdaiņiem, kuri dzelzi uzṇēma galvenokārt no dzīvnieku valsts produktiem, seruma feritīna (SF) līmenis bija normas robežās. SF bija normas robežās 93\% ( $n=26)$, kuri nelietoja pākšaugus. Zīdaiṇu ěšanas paradumi Latvijā dalẹji atbilst vadlīnijām. 63\% zīdaiņu neuzņem pietiekami daudz dzelzs ar uzturu, un DD tika novērots 9,6\% zīdain,u, DDA 4,1\%. Zemāks dzelzs līmenis asin̄̄s bija zīdītiem zīdainiem un zīdainiem, kuriem govs pienu sāka dot agrīnā vecumā; zemāks vidējā korpuskulārā hemoglobīna līmenis bija tiem zīdainiem, kuri saṇēma ekskluzīvo zīdīšanu vismaz pirmos četrus mēnešus; zemāks SF bija zīdītiem zīdaiņiem un zīdaiņiem, kas saṇēma zīdīšanu vismaz pirmos četrus mēnešus, zīdaiņiem, kuru uzturā bija iekḷauti pākšaugi; augstāks serumā šḳīstošo transferāna receptoru līmenis tika novērots zīdainiem, kuri nebija pirmdzimušie. 